\title{
THE PSYCHOLOGY OF THE TRANSFERENCE
}

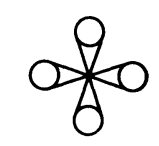

from
The Collected Works of C. G. Jung

VOLUME 16

B O L L I N G E N S E R I E S X X 



\title{
THE PSYGHOLOGY
}

\author{
$\mathrm{OF}$ \\ THE TRANSFERENGE
}

C. G. JUNG

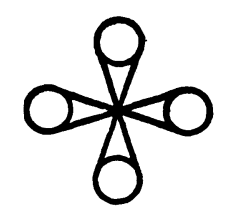

TRANSLATED BY R. F. C. HULL

B O L L I N G E N S E R I E S

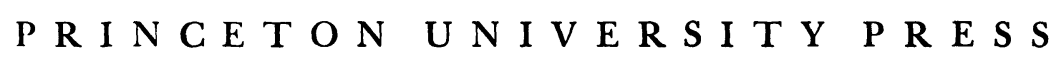


COPYRIGHT 1954 BY BOLLINGEN FOUNDATION INC., NEW YORK, N.Y. NEW MATERIAL COPYRIGHT (C) 1966 BY BOLLINGEN FOUNDATION PUBLISHED BY PRINCETON UNIVERSITY PRESS, PRINCETON, N.J.

Extracted from The Practice of Psychotherapy, Vol. 16 of the Collected Works of C. G. Jung (second edition, 1966). All the volumes comprising the Collected Works constitute number XX in Bollingen Series, under the editorship of Herbert Read, Michael Fordham, and Gerhard Adler; executive editor, William McGuire.

Princeton University Press books are printed on acid-free paper and meet the guidelines for permanence and durability of the Committee on Production Guidelines for Book Longevity of the Council on Library Resources

FIRST PRINCETON / BOLLINGEN PAPERBACK PRINTING, 1969

Third Printing, 1974

Tenth Printing, 1992

LIBRARY OF CONGRESS CARD NUMBER: 72-6530

ISBN 0-691-01752-2

PRINTED IN THE U.S.A.

$\begin{array}{lll}16 & 15 & 14\end{array}$

ISBN-13: 978-0-691-01752-5 (pbk.)

ISBN-10: 0-691-01752-2 (pbk.) 
TO MY WIFE 
